\title{
Policy Storms at the Central Office: Conflicting Narratives of Racial Equity and Segregation at School Committee Meetings
}

\author{
Serena M. Wilcox*
}

\author{
* University of Kentucky \\ College of Education \\ Department Educational Policy Studies \& \\ Evaluation, \\ Lexington, $\mathrm{KY}$, USA. \\ E-mail: swi339@uky.edu
}

\section{Article Info}

Received: March 30, 2020

Revised: May 14, 2020

Accepted: May 17, 2020

\subsection{3/repam.02.01.3}

This is an Open Access article distributed under the terms of the CC BY-NC-ND 4.0 International license.

(https://creativecommons.org/licenses/bync-nd/4.0)

\section{How to cite}

Wilcox, S. M. (2020). Policy storms at the central office: Conflicting narratives of racial equity and segregation at school committee meetings. Research in Educational Policy and Management, 1(2), 40-56.

https://doi.org/10.46303/repam.02.01.3

\begin{abstract}
This article reports findings from a multiyear critical ethnography that examined race talk dilemmas of school leaders at the central office at a small urban school district to understand why racialized educational policies and practices still persist against African American students. This study takes a structural approach to investigating the impact that race talk has on educational policymaking at the local district level. The guiding research question in this paper examines how we can understand educational reform and policy implementation and the unintended consequences of those interventions through the local from a historical context.

\section{KEYWORDS}

School desegregation; structural intersectionality; critical ethnography; structural racism; educational policy.
\end{abstract}




\section{INTRODUCTION}

Policy storms are the confluence of issues in education policymaking and reform efforts (Boylan et al., 2017). Inequalities and privilege are two main concerns of education policy discourse because the distribution of power has greater implications for those who are poor versus those who are affluent. The continuous national refusal to adhere to the 1954 Supreme Court decision in Brown vs. Board of Education to integrate public schools in the United States is central to understanding public school failure and the persistence of unequal educational opportunities for African Americans (Fruchter, 2007). Researching school desegregation requires an analysis of structural racism by highlighting the relationship between marginalized citizens and the legal system in the United States. A structural view of racism reveals how school-community factors affect students of color while taking into account how instances of racial disparities are connected to historical and current sociopolitical policies embedded in white supremacy (Blaisdell, 2016). One of the goals of school integration was to offer quality educational opportunities to all students in public schools. However, quality education is now discussed and measured in educational research by scores on standardized tests and the racebased concept of the achievement gap that public schools around the country are attempting to narrow no matter how segregated the schools may be.

Blakesdale School District (a pseudonym) has a long history of racial inequity regarding African American students. Blakesdale was under a federal consent decree between (20012011). A controlled school choice program and mandatory busing was implemented during the late 1990s and early 2000s in an attempt to desegregate the school district. One of the requirements that Blakesdale had to adhere to in order to end the consent decree was to establish diversity, equity, and inclusion committees that would meet several times a year and work to ensure that the district would provide an equal educational opportunity to all students. School district leaders at Blakesdale formed these committees, but demonstrate little support for racial harmony by convening public meetings that are not well advertised to the public and are not attended by families and other community stakeholders. Conflicting narratives at these meetings reflect interracial intolerance and discriminatory behaviors and practices by school officials at Blakesdale towards marginalized populations in the school district. One of the major dilemmas between policy and practice is that people and agencies who are placed in positions of leadership or problem solvers are the groups that the policies aim to correct (Cohen et al., 2018). The work of education policy is to provide goals and strategies for problem solving. Education policymaking and administration reveal the nexus of power and voice (Diem \& Young, 2015). The disproportion of power is seen discursively by who is allowed to participate in decision-making processes and who those decisions benefit (Diem et al., 2014). Who loses due to a lack of representation in the decision-making process?

The historical purpose of school desegregation policies is connected to ideas of civil rights and educational access for everyone. Since Brown, our public schools have become the 
site where we attempt to deal with racial problems (Ladson-Billings, 2004). Race in this context is defined as a social assemblage that is used to categorize groups of people based on difference and status. A more invisible mode of racism operates through conversation of culture rather than race, difference, and superiority (Gillborn \& Youdell, 2000). The way we think about discrimination influences how politics and policies are structured so that hardships are categorized as singular issues (Crenshaw, 1991). The race talk of school officials at Blakesdale disclose the degree to which their ideologies and tensions about race, class, and gender inform their work and become enacted in local school policymaking, and contribute to personal and professional conflicts. How can we understand educational reform and policy implementation and the unintended consequences of those interventions through the local from a historical context?

\section{The sundown movement and school desegregation policy}

James Loewen (2006) says sundown towns or white ghettos are any organized jurisdiction that restricts African American or other racially minoritized groups from living in towns or suburbs for "all white" purpose (p. 4). Loewen asserts that sundown towns are violent modes of forced segregation that uses illegal local ordinances to bar racial minorities from working in these towns after sunset, owning, or renting residential property. African Americans and other racially marginalized groups who violated these laws were harassed or murdered. Blakesdale was a sundown town and is surrounded by several active sundown towns today. Loewen notes that residential segregation makes it easier to discriminate against African Americans and other racialized populations in schooling, housing, employment, and other city services. Many teachers and educational leaders at Blakesdale school district live in active sundown towns. School desegregation laws and policies threaten the purpose of sundown towns by challenging the idea of equality of public schooling and the stigma of total exclusion (Loewen, 2006, p.171). The sundown town movement teaches us about race relations and the formation and ongoing utility of segregation structurally in the United States.

Blakesdale school district has been entangled with equity lawsuits for several decades. David Gillborn (2013) argues that education policy is an act of white supremacy and is a means to maintain it structurally. Sharon Radd and colleagues (2019) view desegregation policy as a particular kind of education policy that should be examined as a cultural artifact of race-based policy in public education in the United States. Integration ideology during the Civil Rights movement was driven by the idea that racism could end when Blacks were thoroughly interspersed in society (Bell, 1980). Opponents to school integration resist policies that would change the current public school structure that heavily advantage white students over all others. Integrationists believe that racial balance in public schools would also provide an even distribution of resources that white students received over all other students which was one of the benefits the Brown case hoped to achieve. 
Legal scholar Charles Lawrence (1980) says the purpose of school segregation is to subordinate Blacks in society by providing them with inadequate resources and teaching them to feel inferior to whites. He posits that all whites benefit from segregation policies that reduce the educational opportunity for Black students. He asserts that white school officials are complicit in maintaining segregation systemically through school board policies. Lawrence believes that the Brown decision ushered in a post racial way of thinking about race in the United States both within the legal system and society. James Loewen (2006) says that segregation affirms the notion that African Americans are inferior to white people who feel an equal social contract with them should never exist. However, there is no legal recognized right or ethical claim that US citizens have to an educational opportunity (Freeman, 1980). Desegregation of schools is a narrow way of addressing segregation as an institution. Instead, an intentional dismantling of institutional segregation must occur (Ladson-Billings, 2004; Lawrence, 1980).

\section{Discursive policy shifts from equal educational opportunity to closing the achievement gap}

Research by James Crawford (2007) reveal the term achievement gap began to become more widely used in education policy discourse in 1999. He notes that the term was developed by Karl Rove and George W. Bush when No Child Left Behind Act (NCLB) was revised in 2002. All references to equal educational opportunity were replaced with the language of closing the achievement gap. This revision helped shift the way equity was viewed in education policy and changed the focus from providing equal access to resources and opportunity and altered the way we think about accountability (Anderson et al., 2013; Crawford, 2007). NCLB compares test scores by racial categories whereby white students' achievement is measured against African American students. The gap between the test scores of white and Black students is known as the achievement gap (Horsford, 2017; Span \& Rivers, 2012). The term Black-white achievement gap is focused mainly upon achievement between two racial groups while omitting the struggles of other racial and ethnic groups in schools.

Efforts to close the achievement gap has been unsuccessful in U.S. public schools (Darling-Hammond, 2007; Delpit, 2012; Ladson-Billings, 2006; Payne, 2008). The achievement gap has normalized underachievement for African American students (Horsford, 2014). Marguerite Clarke (2007) says that policies similar to NCLB were less likely to close the achievement gap, but rather expand it. She adds that no state has been exceptionally effective at closing the Black-white achievement gap which calls into question the validity of using the standards-based reform model for attaining academic excellence in U.S. education systems. The former discourse of educational opportunity acknowledged that equity, unlike equality, means that the most vulnerable require additional resources, not equal resources (Anderson et al., 2013; Crawford, 2007). The culture of policy framework discloses how policy-driven language and procedures of public schooling conflict with stated equitable aims of racial and ethnic inclusions while promoting systems of stigmatization and deficit thinking strategies 
(Stein, 2004). Gillborn and Youdell (2000) suggests the rationing of education in public schools are concealed from public critique. A major aim in this kind of discourse is to examine the ramifications of education reforms and how they bolster inequities and injustice in public schools.

\section{The nexus between intersectionality, race talk dilemmas, and the resistance to school integration}

What is intersectionlity? What does it do? In her address to the United Nations, Kimberlé Crenshaw (2000a) says that intersectionality is a provisional framework that encompass two forms: 1) structural intersectionality shows how policies intersect with foundational structures of inequality to create compounded injury for vulnerable victims; and 2) political intersectionality refers particularly to how women who are members of marginalized groups organized in different ways to challenge oppressive conditions. Structural intersectionality maps the corporeal consequences of systems of oppression while political intersectionality describes the strategies used to fight against those systems of oppression (Crenshaw, 2014). Intersectionality is the study of how social and structural dimensions of inequality shape social life (Grzanka, 2014). Intersectionality is not theory centered on identities or identity politics, but a sociological concept that is concerned with providing a structural analysis and critique of how social inequalities are produced and maintained (Cho et al., 2013; Collins, 2009; Crenshaw, 2000b; Dill et al., 2001). Crenshaw (2000b) notes that when the most privileged groups are centered in discrimination analyses, it works to marginalize those from more disadvantaged groups. It creates a distorted examination of racism and sexism because the experiences of the under privilege group are grounded in the experiences of the other.

\section{Systems of oppression-The law}

The law is a discursive arena where social norms are created and maintained, and where the social contract is both supported and resisted (Grzanka, 2014). Legal structures are an example of the kinds of structures that intersectional teaching, research, and activism target (2014; p. 1). The law can be understood as a system of oppression in which structural intersectionality demonstrates the ways in which oppressed social groups resist their oppression (Crenshaw, 2000b). The law marks how its historical dimensions are entangled with institutions and stakeholders who have an investment in exploiting difference and the manufacturing of it (Reddy, 2005). Intersectional research examines how major current and historical events exhibit systemic patterns of discrimination, exploitation, privilege, and deprivation such as unfair sentencing practices (Farrell et al., 2010); incarceration and schools (Meiners, 2007); and antidiscrimination law (Crenshaw, 1991) are created and governed by systemic forces that create structures of inequality. School and residential segregation are patterns of systemic oppression that use illegal policies and practices to displace, dominant, and discrimination against marginalized groups. The U.S. Supreme Court in 1917 in the case of Buchanan v. Warley deemed ordinances that excluded African Americans from living in segregated 
communities in Louisville, KY to be illegal (Loewen, 2006). Dorothy Newman (1978) posits that residential separations relies on formal and informal policies and practices that are carefully followed that no legislation has been able to eradicate. Structural intersectionality attempts to capture the structural and material consequences of the interactions between multiple systems of subordination and address the ways the specific policies and practices create inequalities (Crenshaw, 2014). Brown v. Board of Education was a landmark decision that provided an actual legal strategy for not only integrating public schools in the United States, but segregated communities as well.

\section{Race talk dilemmas}

Race talk is a way in which we perceive and talk about race and how language is performed in public (Sue, 2015). Race talk dilemmas are discursive ways in which issues of race, class, and gender are revealed. Race talk is an intersectional discursive framework that provides a lens to investigate the methods used to single out certain groups for discriminatory treatment on the basis of race, class and other forms of oppression. The race talk among school officials in this research illustrates the effects of segregation on the formation of racist ideology of educational leaders in Blakesdale school district. Race talk is intersectional because it provides an intellectual examination of racial issues and dilemmas that helps educational stakeholders perceive and address their own racial practices with clarity (Pollock, 2006), it links the origin of the beliefs and practices to the system(s) that produced it. Counter-narratives of race talk are extremely threatening to whites and to our society because they demonstrate how power and privilege work and how white talk justifies ways in which African Americans and other marginalized social categories are subjugated (Felix \& Trinidad, 2020; Sue, 2015; Bell, 2003). Educational opportunities for marginalized students are mediated by school officials' ideologies of race, class, and gender. Their beliefs about students limit the quality of education the students receive.

\section{METHODOLOGY}

Critical discourse analysis (CDA) is the lens used in this study to analyze how discursive replications of racism, power abuse, and social inequality are form and are sustained structurally. CDA is a kind of discursive analytic used to examine social power abuse, how dominance and inequality are produced and resisted through verbal and texts in the social and political context (Dijk, 2008). Conversations construct social relations and position people categorically as social subjects and is a form of ideology of linguistic material (Fairclough, 1992). Critical refers to illuminating hidden causal effects that require interventions for those who are disadvantaged through processes of change. Anthropologist Faye Harrison (2019) asserts that race does not exist separate from the structural racism that produces and maintains it. She posits that racism is connected to corporeal relations of social and discursive actions that bolster oppressive power associations between groups that are perceived to be 
different. Do educational leaders have the language to critically examine and transform harmful social practices that are encapsulated within current educational policies that create inequitable educational opportunities for all students?

\section{Critical ethnography of racial inequity and race talk dilemmas}

Blakesdale is a small urban school district of $(\mathrm{N}=10,094)$ students located in the Midwestern part of the United States. The racial history of Blakesdale County is complicated by its close proximity to several active sundown towns. All names and locations used in this research are pseudonyms. Fieldwork for this study was conducted over two years with data that documents efforts to desegregate Blakesdale school district over a twenty-year period. For decades, school officials at Blakesdale have grappled with the local African American community to provide racially fair and equitable public education services. Data for this article comes from a larger critical ethnography research project that seeks to disrupt neutrality and assumptions projected into groups of people by revealing obscure operations of power and domination (Madison, 2012). The study examines the impact of race talk on education policymaking structurally at the central district office level. Qualitative research methods in this study employed the use of in-depth interviews, archival data, observations and a critical discourse analyses of public educational documents such as student achievement data, and meeting minutes from the school district. Primary methods used in ethnographic fieldwork are participant observations, in-depth interviews, and document analysis that helps the ethnographer see and make meaning of policy processes systemically (McCarty, 2011; Wolcott, 2008). District school officials at Blakesdale feel that there is no other school district comparable to them and the issues they face to inform school improvement reform. It was important that I used data from the district to speak to them about how their policies, practices, and race talk are central to achieving better educational outcomes for all of their students.

\section{Language Policy}

The APA 7th edition require racial categorical terms like Black and white be capitalized. However, I will not capitalize the term "white" when using it to describe a racial category unless it is the first word in a sentence. Here, I follow the Du Boisian tradition of capitalizing the word Black to acknowledge and render respect on the page for those who the New York Times says have been for generations in the "lower case," (Du Bois, 2007; Tharps, 2014; The New York Times, 1930). Race matters are manifested through public discourse, organizational power arrangements, and social norms and practices (Harrison, 1995). This study is concerned with the discursive dimensions of dominance and by capitalizing the racial category of Black and not white is an act of disrupting the tools of whiteness discursively. The language use in any citations from research data such as school publications, school meeting minutes, code of conduct manuals, archival data, or transcriptions of observation field notes and in-depth 
interviews will not be changed in any way. Citations and references in this article adhere to the APA 6th edition manual style.

\section{Researcher Positionality}

I am an African American working class woman from the rural Southeastern part of the United States. My positionality as a researcher is as an activist-scholar which Michelle Fine (1991) describe as an ethnographer whose position is to disturb hegemonic practices and advocate for marginalized categories by exposing injustices in spaces where disadvantaged people are located while offering alternatives. My interest in small rural and urban schools stem from my own upbringing and education in public schools in the rural Southeastern part of the United States. My personal interests and experiences inform why I chose to conduct this research project. However, I do not believe that the analysis of my findings are limited by those experiences or is diminished by current historical occurrences. This study encompasses the histories of African Americans who have suffered and fought systemic oppression not only in the quest to become educated in formal educational settings, but to be considered citizens of the human race.

\section{RESULTS}

This section begins with a collection of conversations from different school committee meetings at the central district office at Blakesdale around issues of racial equity and school segregation. The race talk that emerged from the committee meetings provide insights into what Ruth Frankenberg (1993) calls the social geography of race. This refers not only to how material space is sorted and inhabited, but also to how space is understood and the kinds of relations that take place within it. The portraits of the race talk dilemmas that occurred at these meetings helps to reveal some of the signs of racial division at Blakesdale and how local manifestations of the city's social geography of race are entangled within school policies and politics.

\section{Portraits of race talk dilemmas from central district office education leaders}

Attack rhetoric blames teachers for public school failure. The degradation of the teaching profession has negatively impacted the job market and has resulted in creating an unstable workforce. Blame is a powerful mechanism for revealing sites of struggle and can be seen as a lazy approach to public deliberation (Hlavacik, 2016). School officials in this context can only be reactive to issues that students bring to school from home, but reject notions of racialized structural behaviors within the school system.

Mr. Jackson [a Black man] reported that LUDA (Large Unit District Association) and the OCR (Office of Civil Rights) asked District representatives to give a presentation on the discipline initiatives the District has implemented which address the goals of SB 100 . He stated that despite the myriad interventions and supports in place, discipline data remains racially disparate with African American students receiving the lion's share of 
disciplinary consequences. Caleb Williams [a white man] responded to Mr. Jackson's comments by laying the responsibility for student misbehavior on their community and families. He stated that schools are held accountable for issues beyond their control. Mr. Jackson stated that although violence in the community and family factors are beyond the schools' control, educators need to do the best they can with students during the seven hours a day they have them, including teaching behavioral expectations that may differ from the expectations students learn at home. Mr. Williams suggested that school expectations be presented to parents via 'road shows' in their communities and explained using scenarios to which parents can relate. One taskforce member suggested having walks in the community to share this information. It was noted that community walks had been held in the past to communicate information about attendance and Community Coalition goals. According to public imagination, public schools are failing at an alarming rate, (DEA committee meeting minutes, 9-10-15).

White educational leaders who live and work in and near sundown towns develop color blind racist rhetoric to explain inequality of social structures like public schooling and use such discourse to justify why achievement gaps persist (Loewen, 2006). Racialized professional talk in these school meetings renders whiteness invisible and reduces the possibility of understanding race talk in these meetings as a deterrent for organizational change (Irby \& Clark, 2018). Racism in the United States has relied on normalizing racialized hierarchy and ideology of white intellectual superiority of over Blacks (Pollock, 2004). An example of this racialization of intellectual superiority can be found in the statement by Mr. William when he suggested that, "school expectations [should] be presented to parents via 'road shows' in their communities and explained using scenarios to which parents can relate." The parents he referred to are African American families in the school district. It is clear that he does not believe that they have the intellectual ability to understand school expectations and thus would need the information presented to them in the form of a "road show" so that they could relate. Mica Pollock (2006) observes that race talk is not just talk, but a discursive lens that allows us to see how we negotiate with racial inequality, and the consequences of those negotiations to harm the most vulnerable students in our public education system. The utility of race talk in this example reveals the presence of structural racism and the ways in which it co-opts the purpose of the discipline, equity and education (DEA) committee's ability to find solutions to racial inequality at Blakesdale.

Despite how Black students perform in school, their teachers often ignore data that does not conform to their prejudices and stereotypes they hold against them (Dumas, 2014; Pollock, 2004; Irvine, 1990). These deficit-based ideologies become embedded in the school's norms, policies, and practices even by teachers who self-identify as good teachers of African American students (Buehler, 2009; Ladson-Billings, 2006). Everyone has something to lose by preserving inequalities in public spaces that allow for public goods to become privatized. A popular idea about why achievement and disciplinary disparities persist among African 
American students is based on a notion that class not race is the reason for low academic achievement for students who are from low-income families (Gordon et al., 2000; Maran, 2000; Portes, 2005). The poverty argument as the causal effect of low achievement and disciplinary issues is problematic. The establishment of the committees have not changed the racial climate at Blakesdale.

Educators can't control what goes on in the home, but they can do their best to meet children's needs during school hours. It was noted that all schools have a small number of students who would benefit from social/emotional instruction done via small groups. Unfortunately, Mr. Jackson pointed out, these groups would be racially identifiable. Mr. Williams commented that the community is segregated, so schools shouldn't be condemned if services are racially identifiable. He said he would support the concept of having separate classrooms in schools to address the small number of students who have more intense needs, (DEA committee meeting minutes, 9-10-15).

Mr. Williams is a member of the Discipline, Equity, and Achievement (DEA) committee and an alternate school board member and he states, "the community [at Blakesdale] is segregated, so schools shouldn't be condemned if services are racially identifiable. He said he would support the concept of having separate classrooms in schools to address the small number of students who have more intense needs," (DEA committee meeting minutes, 9-1015). Mr. Williams' comments on the taskforce have always reflected a segregationist position at Blakesdale. Residential and school segregation is normalize at Blakesdale and Mr. Williams' comments reveal his support for that social arrangement to continue in the school district. As Charles Lawrence (1980) notes once segregation is institutionalized as a labeling device, little maintenance is needed. Any recourse that does not take into consideration the systemic nature of the harm caused by segregation will fail.

\section{Community concerns over the persistence of segregation}

Race talk at Blakesdale is used to assign deficit labels of vulnerability to African American students and their families. Race talk dilemmas of risk, equity, and schooling often view vulnerability as a pathological issue connected to racial groups who are poor, while concealing that vulnerability is also associated with privilege (Khalil \& Brown, 2019; Lee, 2009; Spencer et al., 2006). The local context is important to examine how district leaders promote equity initiatives in order to understand the relevance of how education policies operate (Mattheis, 2017). On December 2019, the local chapters for the American Civil Liberties Union (ACLU) and National Association for the Advancement of Colored People (NAACP) sent a letter to the school superintendent of Blakesdale school district calling out the lack of progress on racial equity. The ACLU, NAACP, and a few members from the Equity and Education Committee (EEC) complained about school segregation and the lack of access to gifted and advanced placement courses for African American students in the district. 
Maggie Johns [white female] is a parent and member of the EEC said "the within-school segregation was extreme" at her daughter's elementary school. She remarked, "Almost all of the white children were in the gifted program, and almost none of the [B]lack children were in the gifted program." The president of the ACLU in Blakesdale noted that since the federal consent decree was lifted from the school district eight years ago, racial equity at Blakesdale has worsen (Local newspaper report, 12/2019). The president of the NAACP said "the consent decree was lifted some time ago... it may exist on paper but in action it hasn't done any good," (Local newspaper report, 12/2019). The ineffectiveness of the consent decree regulate racial equity and compliance to federal laws illustrates the shifting power based the courts have to promote education policy change (Superfine \&Thompson, 2016). A spokesperson for the school district replied to leaders of the ACLU and NAACP saying, "This was a very thoughtful letter. The District takes it seriously and looks forward to having a discussion," (Local newspaper report, 12/2019). EEC member Maggie Johns said that the segregation at her daughter's school is so bad that her daughter and friends thought that "they were going to go into school one day and see the water fountains had also been designated for separate races." Johns said "witnessing all-[B]lack or all-white classrooms in schools sends a huge message to the kids, and it's doing damage every day," (Local newspaper report, 12/2019). Charles Lawrence (1980) believes that the Brown case has not abolished school segregation because the legal system's way of thinking about segregation denied the reality of race and racism in America. Lawrence says the problem of segregation "comes from its "system" or "institution" rather than from "particular segregating acts," (1980, p. 50). Race-conscious education policies like Brown could not address or eliminate racist actions within the classrooms. "The problem was not caused by a limited number of racist actions, but by traditions and practices that embodied and perpetuated deeply entrenched racial inequality even without new discriminatory actions," (Orfield, 2014, p. 274). Amanda Lewis (2003) asserts that schools are one of the fundamental institutions involved in constructing racial categories. Racial categories are ways that people socially create and arrange their identities and behaviors that influence their social experiences and educational outcomes.

\section{DISCUSSION}

Public schools have moved away from using race conscious practices like forced busing to address racial inequity (Petts, 2020). Instead, school committees and taskforces are established with the aim of leading the institutions into becoming more inclusive. The discourse from such committees at Blakesdale school district demonstrate how educational leaders at the central district office grapple with racial equity and school segregation. The local racial history of sundown towns and school segregation is a problem that educational leaders still struggle to address. Many educational leaders at Blakesdale live in active sundown towns and espouse the racist ideologies of social isolation. Policy storms become evident during 
these meetings through professional race talk that reveal the paradox of how white educational leaders who reside in sundown towns deal with educational law, racism, and segregation.

Culture of policy frameworks are created from both historical arrangements and institutional practices (Stein, 2004). Educational research by Mica Pollock (2004) on race talk dilemmas in schools finds that race talk can reveal how silences are systemic when race is situated in a culture of risk in educational settings, it becomes a matrix for determining power and privilege distribution. Education policy narratives have tangible consequences for those whose behavior the policies seek to regulate (Koyama, 2015). The most prevalent discursive tropes in U.S. education policy is related to the achievement gap metaphor. One of the pivotal ways the gap discourse regulates targeted groups is through federal mandated standardized tests (McCarty, 2015). The most effective outcome of culture of poverty discourses has diverted attention away from institutional educational inequities based on race and class in policies viewpoint (Stein, 2004). Therefore, whiteness should be viewed as a social identity that is linked to relations of domination (Frankenberg, 1993). White middle-class norms dominate many schools that creates a culture whereby school officials often have negative views about low-income and marginalized families. The ways in which race talk become evident is the ways in which language reveals the ideologies of school officials which is used to create racialized school environments.

\section{CONCLUSION}

In order to achieve racial equity in public schools requires all educational stakeholders to center the work of structural racism. Public education systems cannot allow organizational immunities that preserve structural racism (Irby \& Clark, 2018; Kegan \& Lahey, 2009). The race talk of school officials at Blakesdale reveals how these local educational leaders resist federal laws and policies that threatens their privilege. One of the major unintended consequences of desegregation policies and equity lawsuits at Blakesdale is that school segregation still continues. One of the implications of this research is to consider how racial equity and policy change should be viewed as institutional work. A policy change as institutional work approach provides an alternative way of thinking about federal policymaking and how those policies are or are not implemented at the local school district level (Svensson \& Tomson, 2017). The institutional work for racial equity and policy change at Blakesdale will require the educational institution and the African American community to contend with the historical issues of structural racism that has prohibited progress in Blakesdale County and the school district. The African American community has consistently filed and won equity lawsuits against Blakesdale School District, and yet racial inequality persists. This may explain why public schools are failing and how current institutional work and policy change for racial equity and achievement exacerbate disparate circumstances that contribute to inequity and achievement gaps. 


\section{REFERENCES}

Anderson, G.L., Mungal, A., Pini, M., Scott, J., \& Thomson, P. (2013). Policy, equity, and diversity in global context: Educational leadership after the welfare state. In Tillman,

L.C., \& Scheurich, J.J. (Eds.), Handbook of Research on Educational Leadership for Equity and Diversity (pp. 43-61). New York: Routledge.

Bell, D. A. (Ed.). (1980). Shades of Brown: New Perspectives on School Desegregation. New York: Teachers College Press.

Bell, L.A. (2003). Telling tales: What stories can teach s about racism. Race, Ethnicity and Education, 6, 3-28.

Buehler, J. (2009). Words matter: The role of discourse in creating, sustaining, and changing school culture. Dissertation. University of Michigan, ProQuest.

Blaisdell, B. (2016). Schools as racial spaces: Understanding and resisting structural racism. International Journal of Qualitative Studies in Education, 29(2), 248-272.

Boylan, H.R., Brown, P.L., \& Anthony, S.W. (2017). The "perfect storm" of policy issues and its impact on developmental education. NADE Digest, 9(1), 2-7.

Cho, S., Crenshaw, K.W., \& McCall, L. (2013). Intersectionality studies: Theory, application, and praxis. Signs: The Journal of Women in Culture and Society, 38, 785-810.

Clarke, M. (2007). State responses to the No Child Left Behind Act: The uncertain link between implementation and "proficiency for all." In C.F. Kaestle \& A.E. Lodewick (Eds.), To Educate a Nation: Federal and National Strategies of School Reform. Lawrence, Kansas: University Press of Kansas.

Cohen, D.K., Moffitt, S.L., \& Smith, K.B. (2018). The influence of practice on policy. In Mitchell, D.E., Shipps, D., \& Crowson, R.L. (Eds.). Shaping Education Policy: Power and Process (2nd edition). New York: Routledge.

Collins, P.H. (2009). Foreword: Emerging intersections-Building knowledge and transforming institutions. In Dill, B.T., \& Zambrana, R.E. (Eds.), Emerging intersections: Race, class, and gender in theory, policy, and practice (pp. viii-xiii). New Brunswick, NJ: Rutgers University Press.

Crawford, J. (2007). A diminished vision of civil rights: No child left behind and the growing divide in how educational equity is understood. Education Week, 26(39), 31, 40.

https://www.edweek.org/ew/articles/2007/06/06/39crawford.h26.html?print=1.

Crenshaw, K.W. (2014). The structural and political dimensions of intersectional oppression. In Grzanka, P.R. (Ed.), Intersectionality: A foundations and frontiers reader (pp. 16-21). Boulder, CO: Westview Press.

Crenshaw, K. (2000a). Background paper for the expert meeting on the gender-related aspects of race discrimination. New York: United Nations.

Crenshaw, K. (2000b). Demarginalizing the intersection of race and sex: A Black feminist critique of antidiscrimination doctrine, feminist theory and antiracist politics. In James, 
J., \& Sharpley-Whiting, T.D. (Eds.) The Black Feminist Reader (pp. 208-238). Malden, MA: Blackwell Publishers.

Crenshaw, K. (1991). Mapping the margins: Intersectionality, identity politics, and violence against women of color. Stanford Law Review, 43(6), 1241-1299.

Darling-Hammond, L. (2007). Race, inequality and educational accountability: The irony of No Child Left Behind. Race Ethnicity and Education, 10(3), 245-260.

Delpit, L. (2012). Multiplication is for White People: Raising Expectations for Other People's Children. New York, NY: The New Press.

Diem, S., Frankenberg, E., \& Cleary, C. (2015). Factors that influence school board policy making: The political context of student diversity in urban-suburban districts. Educational Administration Quarterly, 51(5), 712-752.

Diem, S., \& Young, M.D. (2015). Considering critical turns in research on educational leadership and policy. International Journal of Educational Management, 29(7), 838850.

Diem, S., Young, M.D., Welton, A.D., Mansfield, K.C., \& Lee, P.L. (2014). The intellectual landscape of critical policy analysis. International Journal of Qualitative Studies in Education, 27(9), 1068-1090.

Dill, B.T., Nettles, S.M., \& Weber, L. (2001). Defining the work of the consortium: What does we mean by intersections? Connections. Consortium on Race, Gender and Ethnicity. http://www.crge.umd.edu/pdf/RC2001_spring.pdf.

Dijk, T.A. van. (2008). Discourse \& Power. New York: Palgrave Macmillan.

Du Bois, W.E.B. (2007). The Philadelphia Negro. (The Oxford W.E.B. Du Bois). New York: Oxford University Press.

Dumas, M.J. (2014). "Losing an arm": Schooling as a site of black suffering. Race, Ethnicity and Education, 17(1), 1-29.

Fairclough, N. (1992). Discourse and Social Change. Cambridge, England: Polity Press. Farrell, A., Ward, G., \& Rousseau, D. (2010). Intersections of gender and race in federal sentencing: Examining court contexts and the effects of representative court authorities. Journal of Gender, Race and Justice, 14, 85-126.

Felix, E.R., \& Trinidad, A. (2020). The decentralization of race: Tracing the dilution of racial equity in education policy. International Journal of Qualitative Studies in Education, 33(4), 465-490.

Fine, M. (1991). Framing Dropouts: Notes on the Politics of an Urban Public High School. NY: State University of New York Press.

Frankenberg, R. (1993). White Women, Race Matters: The Social Construction of Whiteness. Minneapolis: University of Minnesota.

Freeman, A.D. (1980). School desegregation law: Promise, contradiction, rationalization. In Bell, D. A. (Ed.), Shades of Brown: New Perspectives on School Desegregation (pp. 7189). New York: Teachers College Press. 
Fruchter, N. (2007). Urban Schools, Public Will: Making Education Work for All Our Children. New York: Teachers College Press.

Gillborn, D. (2013). The policy of inequity: Using CRT to unmask white supremacy in education policy. In Lynn, M., \& Dixson, A.D. (Eds.), Handbook of Critical Race Theory in Education (pp. 129-139). London, UK: Routledge.

Gillborn, D., \& Youdell, D. (2000). Rationing Education: Policy, Practice, Reform and Equity. Philadelphia: Open University Press.

Gordon, R., Piana, L.D., \& Keleher, T. (2000). Facing the Consequences: An Examination of Racial Discrimination in the U.S. Public Schools. Oakland, CA: Applied Researcher Center.

Grzanka, P.R. (2014). Systems of oppression. In Grzanka, P.R. (Ed.), Intersectionality: A Foundations and Frontiers Reader (pp.1-5). Boulder, CO: Westview Press.

Harrison, F.V. (2019). Unraveling race for the twenty-first century. In MacClancy, J. (Ed.), Exotic No More: Anthropology for the Contemporary World (pp. 77-103). Chicago: The University of Chicago Press.

Harrison, F.V. (1995). The persistent power of "race" in the cultural and political economy of racism. Annual Review of Anthropology, 24, 47-74.

Hlavacik, M. (2016). Assigning blame: The rhetoric of education reform. Cambridge, MA: Harvard Education Press.

Horsford, S.D. (2017). A race to the top from the bottom of the well? The paradox of race and U.S. education reform. The Educational Forum, 81(2), 136-147.

Horsford, S.D. (2014). When race enters the room: Improving leadership and learning through racial literacy. Theory Into Practice, 53(2), 123-130.

Irby, D.J., \& Clark, S.P. (2018). Talk it (racism) out: Race talk and organizational learning. Journal of Educational Administration. DOI: 10.101108/JEA.01.2018-0015.

Irvine, J.J. (1990). Black Students and School Failure: Policies, Practices, and Prescriptions. New York: Greenwood Press.

Kegan, R., \& Lahey, L. (2009). Immunity to Change: How to Overcome It and Unlock the Potential in Yourself and Your Organization (Leadership for the Common Good). Boston, MA: Harvard Business Review Press.

Khalil, D., \& Brown, E. (2019). Diversity Dissonance as an Implication of One School's Relocation and Reintegration Initiative. Educational Administration Quarterly. https://doi.org/10.1177/0013161X19868511.

Koyama, J. (2015). When things come undone: The promise of dissembling education policy. Discourse: Studies in the Cultural Politics of Education, 36(4), 548-559.

Ladson-Billings, G. (2006). From the achievement gap to the education debt: Understanding achievement in U.S. schools. Educational Researcher, 35(7), 3-12.

Ladson-Billings, G. (2004). Landing on the wrong note: The price we paid for Brown. Educational Researcher, 33(7), 3-13. 
Lawrence, C. (1980). "One More River to Cross" - Recognizing the real injury in Brown: A perspective to shaping new remedies. In Bell, D. A. (Ed.), Shades of Brown: New Perspectives on School Desegregation (pp. 49-68). New York: Teachers College Press.

Lee, C.D. (2009). Historical evolution of risk and equity: Interdisciplinary issues and critiques. Review of Research in Education, 33, 63-100.

Lewis, A.E. (2003). Race in the Schoolyard: Negotiating the Color Line in Classrooms and Communities. New Brunswick, NJ: Rutgers University Press.

Loewen, J.W. (2006). Sundown Towns: A Hidden Dimension of American Racism. New York: Simon \& Schuster.

Madison, D.S. (2012). Critical Ethnography: Method, Ethics, and Performance. Thousand Oaks, CA: SAGE Publications.

Maran, M. (2000). Class Dismissed: A Year in the Life of an American High School: A Glimpse into the Heart of a Nation. New York: St. Martin's Press.

Mattheis, A. (2017). Central district office leadership for diversity and equity. Journal of School Leadership, 27, 521-552.

McCarty, T. L. (2015). How the Logic of Gap Discourse Perpetuates Education Inequality: A View from the Ethnography of Language Policy. Journal of Linguistic Anthropology, 25(1), 70-72.

McCarty, T.L. (2011). Entry into conversation: Introducing ethnography and language policy. In McCarty, T.L. (Ed.). Ethnography and Language Policy. New York: Routledge.

Meiners, E.R. (2007). Right to be hostile: Schools, prisons, and the making of public enemies. New York, NY: Routledge.

"NEGRO" WITH A CAPITAL "N.". (1930, Mar 07). New York Times (1923-Current File) Retrieved from

\section{https://searchproquest.com.proxy2.library.illinois.edu/docview/98721509?accountid=1} $\underline{4553}$

Newman, D. K. (Ed.) (1978). Protest, politics, and prosperity: Black Americans and white institutions, 1940-75. New York: Pantheon Books.

Orfield, G. (2014).Tenth Annual Brown Lecture in Education Research a New Civil Rights Agenda for American Education. Educational Researcher, 43(6), 273-292.

Payne, C. (2008). So Much Reform, So Little Change: The Persistence of Failure in Urban Schools. Cambridge, MA. Harvard Education Press.

Petts, A.L. (2020). It's all in the definition: Color-blind interpretations of school diversity. Sociological Forum. DOI: 10.1111/socf.12590.

Pollock, M. (2006). Race wrestling: Struggling strategically with race in educational practice and research. In Spindler, G.D. (Ed.), New horizons in the ethnography of education (pp. 83-126). Mahwah, NJ: Lawrence Erlbaum Associates, Inc. Publishers.

Pollock, M. (2004). Colormute: Race Talk Dilemmas in an American School. Princeton, NJ: Princeton University Press. 
Portes, P.R. (2005). Dismantling Educational Inequality: A Cultural-Historical Approach to Closing the Achievement Gap. New York: Peter Lang.

Radd, S.I., Grosland, T.J., \& Steepleton, A.G. (2019). Desegregation policy as cultural routine: A critical examination of the Minnesota Desegregation Rule. Journal of Education Policy. DOI: 10.1080/02680339.2019.1609092.

Reddy, C. (2005). Asian diasporas, neoliberalism, and family: Reviewing the case for homosexual asylum in the context of family rights. Social Text, 23, 101-119.

Rivers, I., Poteat, V.P., Noret, N., \& Ashurst, N. (2009). Observing bullying at school: The mental health implications of witness status. School Psychology Quarterly, 24, 211-223.

Span, C.M., \& Rivers, I.D. (2012). Reassessing the achievement gap: An intergenerational comparison of African American student achievement before the compensatory education and the Elementary and Secondary Education Act. Teachers College Record, 114, 1-17.

Spencer, M. B., Harpalani, V., Cassidy, E., Jacobs, C, Donde, S., \& Goss, T. N. (2006). Understanding vulnerability and resilience from a normative development perspective: Implications for racially and ethnically diverse youth. In Cicchetti, D., \& Cohen, E. (Eds.), Handbook of Developmental Psychopathology (pp. 627-672). Hoboken, NJ: John Wiley.Stein, S.J. (2004). The Culture of Education Policy. New York: Teachers College Press.

Sue, D.W. (2015). Race Talk and the Conspiracy of Silence: Understanding and Facilitating Difficult Dialogues of Race. Hoboken, NJ: Wiley.

Superfine, B.M., \& Thompson, A.R. (2016). Interest groups, the courts, and educational equality: A policy regimes approach to Vergara v. California. American Educational Research Journal, 53(3), 573-604.

Svensson, J., \& Tomson, K. (2017). Policy change as institutional work: Introducing cultural and creative industries into cultural policy. Qualitative Research in Organizations and Management: An International Journal, 12(2), 149-168.

Tharps, L.L. (2014). The Case for Black with a Capital B. The New York Times. www.nytimes.com/2014/11/19/opinion/the-case-for-black-with-a-capital-b.html. Wolcott, H.W. (2008). Ethnography: A Way of Seeing (2 ${ }^{\text {nd }}$ ed.). Lanham, MD: AltaMira Press. 